\title{
The Demiurge and His Place in Plato's Metaphysics and Cosmology
}

\author{
Viktor Ilievski
}

Close to the beginning of his grand speech, Plato's Timaeus makes the following declaration: "To find the maker and father of this universe is a difficult task, and even once found, it's impossible to declare him to all" (Timaeus 28c3-5). This is certainly not meant to be taken as a hyperbole, for the inquiry into the cause of creation must indeed be an arduous and unpredictable one. Now, the Timaean maker and father ${ }^{1}$ was made famous under another appellation, one much less straightforward and much more perplexing than the former twoho démiourgos. It turns out that pinpointing the Demiurge's status within Plato's metaphysics is a task almost as difficult as pursuing the contemplative effort needed to attain to poièten kai patera himself. In fact, this seems to be the only indubitable thing regarding the Demiurge, as demonstrated by both the ancient divergence of opinions and the contemporary debates.

My purpose in this chapter is not to settle the differences over the ontology and the cosmogonical role of Plato's creator-god, for that could be too ambitious a task. Instead, I pursue a more modest aim, which is to offer a further contribution toward the resolution of this long-standing dispute by considering and combining certain aspects of my predecessors' views, perhaps adding a distinct flavor to the mixture. In short, my intention is to argue that the Timaean divine craftsman stands for a transcendent Intellect, which is not only a productive cause, ${ }^{2}$ but also the highest god and the ultimate creative

1 The latter is the only "biological" metaphor applied to the Demiurge. For some Middle Platonic interpretations of Plato's intentions behind this double predication, see Voerwerk 2010, 79-94.

2 Throughout this chapter, I shall use "cause" to express the Greek notion of aitia/aition, instead of the alternative "explanation", "reason", etc. This is for two reasons: a) it is neither wrong nor outlandish to render aitia/aition with "cause", and the instances in the scholarly literature that demonstrate this are too numerous to mention; b) unless specified otherwise, it is employed here in the sense of an active force or agent that brings about or produces something, which is close to the modern idea of cause. For the interrelatedness of the notions of explanation, reason, cause, and some peculiarities regarding the last one, see Hankinson 2001, 4-5. 
principle of Plato's late metaphysics. Section three below is dedicated to this endeavor. In order to accomplish this aim, it will first be necessary to provide a concise outline of the most important views on the Demiurge circulated among the ancients, as well as those from recent times. This task is carried out in sections 2.1 and 2.2 of this chapter.

\subsection{The Opinions of the Ancients}

The objective of this section is primarily historical in nature. It is meant to explicate as clearly as possible the most prominent ancient stances on the Demiurge, but also to indicate what seems to be a developmental interpretative trend that culminates in recognizing him as a separate nous, different from both the World Soul and the Good.

The Timaeus became a subject of discussion very early on. ${ }^{3}$ The enigmatic creator accentuated in the dialogue had already raised his share of controversies in the Old Academy and the Lyceum, a fact perhaps best exemplified by the awkward silence surrounding him. Thus, Aristotle chose to ignore demiurgic activity and its causal impact, ${ }^{4}$ though he did not refrain from criticizing Plato's account of the world's temporal beginning. ${ }^{5}$ Aristotle's depreciating remarks might have further prompted Speusippus and Xenocrates to assess the dialogue's cosmogony as a mere didactic device, ${ }^{6}$ and to exclude the Demiurge per se from their metaphysics. ${ }^{7}$ Besides, the non-literal interpretation, implied in the assumption that the account has a solely didactic purpose, was not

3 As attested by Proclus' remarks on Crantor, the dialogue's first commentator (Proclus, In Ti. I. 76.1-2). See Tarrant 2006, 168-69. For a more detailed analysis of Plutarch's and Proclus' testimonia regarding Crantor's commentary, see Dillon 2003a, 218-24.

4 This is made clear by Aristotle's assertion that Plato recognizes only two types of cause: the material and the formal (see Metaph. 988a7-15).

5 Cael. 279b17-28oa1o, 28oa27-32. For further references to Aristotle's works and scholarly literature on the subject, see Karamanolis 20o6, 29 and ns. 89-92. This criticism, of course, reflects his own reading of the Timaeus, which could have been either sincere or tendentious. Dillon (2003a, 25) cautiously opts for the second alternative, while O'Brien $(2015,24-25)$ is rather adamant that Aristotle's motivation was to weaken his opponent's position by purposefully enunciating the seemingly absurd idea of a universe created at a specific point in time.

6 Speusippus frs. 61a-b Tarán, Xenocrates frs. 153-58 Isnardi Parente.

7 Although Speusippus' god, the maker of the universe, uses the decade as the paradigm of his creation (fr. 28.9-14), Xenocrates' Monad is lauded as the primary god, nous, and the universal father, also known as Zeus (fr. 213.1-4). Both these entities are obvious heirs of the deconstructed Demiurge. 
peculiar to Speusippus and Xenocrates alone-it seems that all other known members of the Old Academy, from Philippus of Opus ${ }^{8}$ to Crantor, subscribed to it. ${ }^{9}$

Antiochus of Ascalon (c. 130-68 BC) has been lauded as the thinker whose work restored the old doctrines and thus marked the beginning of Middle Platonism. ${ }^{10}$ The demise of skepticism in the Academy and the re-emergence of the "dogmatic" approach to philosophizing naturally brought back to the fore the need to interpret Plato's dialogues anew, with the Timaeus gaining a place of honor. Nonetheless, when it comes to the details of its cosmological account, Antiochus seems to have remained loyal to the tradition established in the Old Academy and neglected Plato's craftsman-god once again. The Demiurge is excluded from Antiochus' physics, or rather fused with the World Soul (which is also the nous and pronoia that directs and cares for the universe), ${ }^{11}$ whose supremacy had already been postulated by Philippus of Opus.

The divergence from a general tendency to neglect the Demiurge was possibly heralded by the apocryphal Peri physios kosmō kai psychas, attributed to Timaeus Locrus $(T L)$. The text represents a synopsis and partial exegesis of the Timaean cosmogony, psychogony, and human physiology. It is written in Doric dialect, ${ }^{12}$ abounds with Peripatetic and Middle Platonic vocabulary, and also displays some possible Stoic and Neopythagorean influences. The point I want to draw attention to is that $T L$, while epitomizing Timaeus $27 \mathrm{~d}-30 \mathrm{O}$ and listing

8 For Philippus, the supreme principle and the creator of all that is was the World Soul. See Dillon 2003a, 185-89, Epin. 983b-988e.

9 As far as the early interpretation of Timaean metaphysics is concerned, Dillon $(2003 \mathrm{~b}$, 81) — having in mind primarily Speusippus and Xenocrates—writes: "What we are left with $[\ldots]$ is $[\ldots]$ on the one hand a primal deity who is an intellect, the content of which are a matrix of Forms $[\ldots]$ and a World Soul, holding a median and mediating position in the universe, containing elements that enable it $[\ldots]$ to transmit the Forms now in the guise of quasi-arithmetic, or rather geometric, entities [...] as the building blocks of the physical world." The Receptacle is only "logically" prior to the organized world since the latter is beginningless. All efficient causal power is delegated to the World Soul. However, see Sedley (2002, 69), who claims that Polemo and those around him revived the primeval-act-of-creation interpretation.

10 See Karamanolis 2006, 44; Bonazzi 2012. However, cf. Dillon 1996, 84. For a clear explication of the thesis that Antiochus' metaphysics was more closely aligned with the Stoic position than with that of Plato or the later Platonists, see Boys-Stones 2012. A disagreement with this position is expressed in Bonazzi 2012, 312-14. Finally, for a detailed list of the possible "founders" of Middle Platonism and the relevant bibliography, see BoysStones 2018, 15-16.

11 See Dillon 1996, 82-83.

12 Which is, together with the author's name, one of the primary reasons why it has been included among the Pseudopythagorica. 
the entities existent before the formation of the heavens, identifies them as Form (idea), matter (hyla), and the craftsman-god (theos demiourgos) who, being good, transformed initial disorder into order (TL 94c). ${ }^{13}$ Hence, we finally have an explicit invocation of Plato's Demiurge as he appears in the Timaeus. ${ }^{14}$ Although $T L$ 's date and origin remain shrouded in mystery, ${ }^{15}$ it deserves a brief mention at this juncture, because the text probably (re)gained its importance sometime toward the end of the first century AD. ${ }^{16}$

Incidentally, these were also the years when Plutarch of Chaeronea flourished. He, inter alia, did everything he could to turn the interpretative tide in favor of the literal reading of the Timaeus. In De animae procreatione in Timaeo (1013A-B and $\left.{ }_{1013} \mathrm{E}-\mathrm{F}\right)$, Plutarch expresses strong disagreement with his colleagues from the Old Academy, Xenocrates and Crantor-but also mentions the later Eudorus disapprovingly — regarding both the soul's composition and the generation of the universe. ${ }^{17}$ Plutarch's motivation for treading this scarcely

13 These are to become the emblematic Middle Platonic principles.

14 Indeed, this statement is all but uncontroversial. $T L$ does not endorse a factual primeval act of creation ("before, according to the account, the heavens came to be," $\pi$ piv $\hat{\omega} v$

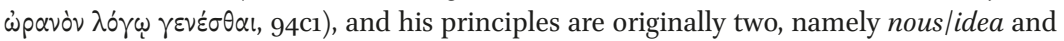
ananke or hyla (93a-94a); nevertheless, this could be mendable with the help of the Middle Platonic (and also — at least sporadically_earlier) assumption that the Forms are contained within god's mind (see Dillon 1993, 94-95), or perhaps soul (see Karamanolis 2006, 169).

15 To make a long story undeservingly short: Taylor $\left(1928,655^{-64}\right)$ proposes the first century $\mathrm{AD}$; Thesleff $(1961,62)$ cautiously mentions $300 \mathrm{BC}$ as a possible date for the original manuscript; Baltes $\left(1972,105^{-106)}\right.$ argues that $T L$ is later than Antiochus (125-68 BC); Dillon $(1996,131)$ thinks that it is later than Eudorus of Alexandria; the most revolutionary is Ryle's proposal (1965): what we actually have is an early work of Aristotle.

16 The first recorded quotation being found in Nicomachus of Gerasa (see Thesleff 1961, 6o, 64).

17 A possibly peculiar point is that he gives no clues of any allies in the struggle to re-establish Plato's true teaching. This is, on the one hand, in conformity with the fact that Proclus (In Ti. I. 381.26-382.1) makes no reference to earlier thinkers other than "those around Plutarch and Atticus," who advanced the doctrine of creation in time - which is a commonly used but imprecise idiom. Since time arose together with the universe, there cannot be a "creation in time" proper, as also Boys-Stones 2012, 185. Perhaps the only Platonist who speaks of proto-time that precedes the orderly one is Atticus, In Ti. I. 276.31-277.7, 286.26-29. Plutarch has the "formless matter" of time, Quaest. Plat. viII 1007A-C). On the other hand, it stands_-again, possibly —in opposition to Proclus' claim that Plutarch, Atticus, and "many others among the Platonists" had a temporal understanding of the world's generation. Cherniss $(1976,176 \mathrm{n}$. a) and Sedley $(2007,107)$ name and identify some Greek and Roman philosophers, both earlier and later, who adhered to the doctrine of temporal creation, while Sorabji $(1983,268-75)$ offers a more detailed account of the debate. As a solution to Plutarch's silence and the seeming inconsistency with Proclus' 
explored path was his conviction that, if he were to do otherwise, he would not remain faithful to Plato and the real purport of the Timaeus. In order to avoid this pitfall, he disassociates himself from his predecessors, against whom two charges are issued: (a) they are keener to promote their own ideas than to say something in conformity with Plato's own words (1013B); (b) they are embarrassed (probably on the strength of Aristotle's criticism) by what Plato actually wrote, and feel obliged to twist and deny the plain doctrinal truth of generation in time. The intricacies of Plutarch's attempts to reconstruct Plato's "true" metaphysics and cosmogony cannot be a subject of interest here. Nevertheless, one detail should not pass unnoticed: although far from evident, it is at least probable that Plutarch associated his highest god with the Timaean Demiurge, ${ }^{18}$ besides identifying the same entity with the Good, the One, and the Paradigm, ${ }^{19}$ which is an unsurprising offshoot of the literal reading.

Plutarch may thus be described as responsible for reinstating the Demiurge's dignity, if for no other reason than because he did not interpret him away, as well as because he disassociated the demiurgic activities from the World Soul and ascribed them to a higher entity. His later ally and follower, Atticus, went a step further. Although Dillon writes that for Atticus, "the Demiurge and the World Soul have merged into the more 'modern' and 'scientific' conception of the Logos," ${ }^{20}$ evidence found in the preserved fragments urges us to the conclusion that his literal reading of Plato's dialogues and his pious inclinations made him attribute a metaphysical place of honor to the Timaean Demiurge and interpret the act of creation as a craftsman-like activity.

These points are made abundantly clear. From fr. 3 (des Places), we learn that god is good, that he orders everything, and that his providence extends all the way to the realm of men; from fr. 4, that god is the most beautiful craftsman and architect, responsible for the universal order, and that his creative act is factual, ${ }^{21}$ from fr. 9 , that Atticus conceived of god as the father, guardian, and

second statement above, Cherniss proposes that Plutarch might have been the first Platonist to embrace that interpretation, all those anterior to him being Peripatetics.

18 See Quaest. Plat. 100oE; Quaest. conv. 720A-C.

19 Plutarch possibly identifies the creator with the Paradigm in Quaest. Plat. 1007D. A relatively extensive argument, to the effect that Plutarch's god is the Demiurge, but also the Paradigm (and how that is unproblematic), is given in Ferrari 2005. See also Karamanolis 2014, section 4.3; however, cf. Dillon 2002, 224-229. It has to be admitted that Plutarch's theology remains a contentious subject.

20 Dillon 1996, 252. It is also true that, only two pages later (254), Dillon writes: "Atticus made the Demiurge his supreme God, identifying him with The Good, and calling him also Intellect (nous)."

21 The importance of divine craftmanship and providence for Atticus and other Middle Platonists is stressed in Chiaradonna 2015, $3^{-}-39$. 
Demiurge; from fr. 12 , that he equated the Demiurge with the Good; ${ }^{22}$ from frs. 13 and 23, that god, the Demiurge, also causes in a demiurgic fashion, as a carpenter; from fr. 28 , that Atticus considered the Demiurge to be the first god; from fr. 34, that he placed the Demiurge above the Paradigm, and so on. Hence, Plato's Demiurge is not only alive and well in Atticus, but also elevated to the position of the supreme cause, the Good itself, who, in creating the phenomenal world, utilizes the rest of the intelligibles as models. The same is true for Alcinous, who deserves at least a brief mention here. He discusses mature Middle Platonism's three paradigmatic principles—god, Forms, matter-and equates the first one, i.e., the primary Intellect, with the Good (in Didascalicos 10.3). Alcinous is also probably the most familiar name in the group claimed by Petrucci to represent "the other side of Middle Platonism," its principal spokesperson being Taurus. ${ }^{23}$

The last philosopher counted among the Middle Platonists ${ }^{24}$ to be mentioned in this overview is Numenius. ${ }^{25}$ In fact, he has also been classified as belonging to the eclectic and diverse group of Neopythagoreans, because, although he accepted Plato's authority almost without reserve, Numenius believed that Plato had acquired his wisdom from Pythagoras, and that he had actually been a Pythagorean himself.26 Be that as it may, what really counts is that Numenius based his speculations almost exclusively on Plato's dialogues-giving the Timaeus a place of prominence - and that his metaphysical system, as well as the Demiurge's status within it, were rather novel and proved very influential.

As reported by Calcidius in his rather long testimony on Numenius' first principles (In Platonis Timaeum commentarius 297.7-301.20 Waszink), the latter took matter (dualitas) to be ungenerated and coeval with god (singularitas)

22 See also Karamanolis 2006, 162.

23 Petrucci argues extensively and persuasively that they are literalists (like Plutarch and Atticus), but nevertheless reject creation in time (like Timaeus Locrus), and, unlike the other Middle Platonists, adopt a non-craftsman-like theory of causation. For an illumination of the exegetical approach that combines literalism and sempiternalism, see Petrucci 2018, ch. 2. For the non-demiurgical cosmogony of Taurus and Alcinous see Petrucci 2018, 76-91 and 99-104, respectively.

24 A concise but meticulous overview of the defining characteristics of Middle Platonism and of the intellectual and doctrinal context within which it developed, accompanied by rich bibliography, is given in Boys-Stones 2018, 12-23.

25 He was probably senior to Atticus. I discuss the latter immediately after Plutarch simply because the two of them share many interpretative commonalities.

26 See fr. 24. 57-70 des Places. A conveniently succinct but highly informative analysis of Numenius' dating, works and philosophy is given in Karamanolis 2013. 


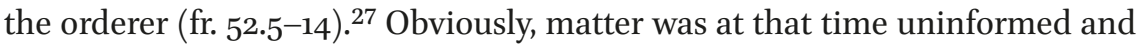
in need of ordering. This task was undertaken and successfully executed by the Timaean Demiurge. However, unlike Atticus, and possibly Plutarch, Numenius declined to identify him with either the Good or the first god, fearing that contact with matter would blemish him to some degree, as well as that the contemplation of the Forms would divide his thought. ${ }^{28}$ Hence, he postulates an entity beyond the Demiurge, the first Intellect (fr. 17), which is utterly simple (fr. 11), unmoved (fr. 15), and inactive (fr. 12). The first Intellect is the Good itself, and it is only by participation in it that the Demiurge acquires his own goodness (frs. 19, 20). As a matter of fact, Numenius is careful to insulate his second god from contamination with matter as well. His only activities are contemplation of the Forms and reflection on how to impose them on the unlimited duality. In order to perform this task, the Demiurge splits into a third god (frs. $11,16,21)$, who thinks discursively and through whom the second god creates (fr. 22). These are the three gods, or Intellects, that Numenius exalts: "the first one he calls 'Father', the second one 'Maker', while the third 'What is Made'" (fr. 21.1-3). Thus, Numenius' divinities seem to stand, respectively, for the Good (of Republic 508e), the Timaean Demiurge, and the World Soul of the Timaeus, also identified with the god which is the universe itself. In this way Numenius preserves the Demiurge but grants him a subordinate status in relation to the highest principle, the first god.

The thinker who popularized the triadic structure above and made it the standard metaphysical schema for Platonists to come was Plotinus. Although his three hypostases do diverge from Numenius' gods in nature ${ }^{29}$ and elaboration, there were rumors circulating — even during his lifetime - that he had plagiarized the latter and presented the appropriated teachings as his own. This is reported by Porphyry (Vita Plotini 17), who is quick to add that Amelius responded to these allegations and wrote a treatise — unfortunately lost - that vindicates Plotinus by underlining the doctrinal differences between the two philosophers.

27 This strongly indicates a literal approach to the Timaeus. As Dillon $(1996,374)$ notes, what is lacking is a clear confirmation that he also believed in a factual act of creation. Of course, the absence of testimonia in the already scarce fragments does not prove that he did not.

28 See Karamanolis 2006, 140.

29 E.g., the Good of Plotinus, unlike Numenius', is not an Intellect, remains unconcerned even with intelligible objects, and is beyond intellection (see Enn. v.6). 
Despite the undisputable similarities, ${ }^{30}$ as far as the exegesis of the Timaeus is concerned, Plotinus clearly subscribes to the allegorical reading. For him, the process of creating the sensible world does not involve any prior planning or deliberation, or exercise of craftmanship; ${ }^{31}$ Plato speaks of calculation and foresight that apparently antedate the universe's generation, only to indicate that it is constituted as if it were a product involving most excellent advance planning. ${ }^{32}$ Once again, the figure of the creator is thoroughly "demythologized." What, then, has become of the Demiurge in Plotinus? Although it may seem at first that no unequivocal answer can be given, ${ }^{33}$ on closer inspection it becomes abundantly clear that Plotinus assimilated Plato's Demiurge to his second hypostasis, the Intellect. Thus, most emphatically, Ennead II.3.18.1416: "and over all things is nous, the Demiurge, who gives also to the soul, which is after him,"34 as well as v.1.8.5-6: "For his Demiurge is the nous. And he says that the former creates the Soul in that mixing bowl."35 This, with more or less variation, will remain a standard interpretation for the Platonists that follow.

Plotinus' most eminent disciple, Porphyry, was an advocate of the non-literal reading of the Timaean creation story. ${ }^{36}$ Consequently, like Plotinus and unlike Atticus, he rejected the act of demiurgy as a temporal phenomenon, and endorsed instead the concept of an everlasting demiurgic process exercised upon the cosmos by god. ${ }^{37}$ Now, Proclus, while discussing his predecessors' opinion on the Demiurge, makes Porphyry profess that the Demiurge is

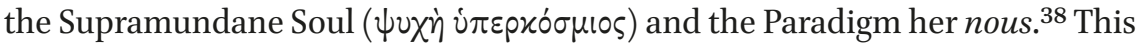

30 Plotinus probably would not have been interested in denying such similarities-after all, he did not consider himself the founder of a new branch of Platonism, but a faithful follower of Plato and the tradition he had the privilege to interpret correctly (see, e.g., Enn. v.1.8.11-14). The trinity of principles, as Plotinus saw the issue, was in any case not Numenius' contribution, but an esoteric doctrine of Plato (which Numenius, to a degree, misunderstood), made evident in the Second Letter $312 \mathrm{e}$.

31 See Enn. vi.7.1-7.

32 Enn. VI.7.1.30-35. See also Noble and Powers 2015, 53.

33 See Enn. IV.4.10.1-9. Proclus (In Ti. I. 305.16-20) claims that, for Plotinus, the Demiurge is double, that is, represented by both the Intellect and the World-Soul (although only a little later he denies that Plotinus ever associated the Demiurge with the latter, In Ti. I. 307.4-7). See also Chiaradonna 2015, 32.

34 Unless noted otherwise, the translations from Greek are mine.

35 See also II.9.6.61, where Plotinus rebukes the Gnostics for identifying the Demiurge with the World Soul and III.9.1.1-3, where he seems to use ho demmiourgos as a synonym for ho nous.

36 For some of Porphyry's arguments against the literal reading and his explanation of the reasons behind Plato's positing of pre-cosmic disorder, see Proclus, In Ti. I. 394. 8-31.

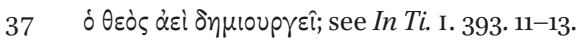

38 In Ti. I. 306.31-307.4. See also I. 431.20-23. 
is certainly a curious assertion. ${ }^{39}$ Elsewhere, i.e., in his exposition of Porphyry's criticism of Atticus (In Platonis Timaeum commentarii I. 391-396), Proclus claims that the former delegates the demiurgic power to god the Intellect, who is also called the primary cause and principle ${ }^{40}$ and for whom Plato's Demiurge of the Timaeus stands. ${ }^{41}$ There are thus some little uncertainties regarding Porphyry's position on the Demiurge. Still, considering that he was an anti-literalist and a staunch adherent to Plotinus' metaphysics, it seems safe to conclude that, for him, Plato's Demiurge had been a symbol of the second hypostasis, the Intellect, which encompasses the Forms and constantly re-creates the universe by applying the seminal logoi on it.

The hierarchic proliferation of ontological principles, which reached its peak in the work of Proclus, had been introduced into Platonic metaphysics by Porphyry's disciple Iamblichus. As we learn from Proclus (In Platonis Timaeum commentarii I. 307.17-25), the simplified version of his position on the Demiurge is consistent with the principal view of Plotinus, i.e., he is identified with the intelligible cosmos. Its more detailed exposition, however, demonstrates that Iamblichus' conception does not differ much from Proclus'. ${ }^{42}$ The latter explicates this interpretation, which he modestly claims is derived from Syrianus' teachings, in his commentary on the Timaeus, I.310.3-319.21. It is impossible to dwell here on the intricacies of Proclus' chain of principles, yet a failure to understand it makes grasping the identity and status of his Demiurge impossible. Therefore, in what follows, I give a rudimentary sketch of the relevant hypostasis.

On the one hand, Proclus adopts the standard Neoplatonic progression of One, Intellect, and Soul, with matter being the final and lowest stage of the One's creative output. On the other hand, following Iamblichus, he asserts

39 "It does not look as if Proclus has made an honest attempt to give a fair account of Porphyry's view" (Opsomer 2006, 275). On the same and the next page Opsomer gives an account of both the reason behind Proclus' error and the possible purport of Porphyry's alleged statement.

40 See Proclus, In Ti. I. 393. 23-27, Philoponus, De aet. mundi 172. 5-15. However, cf. In Ti. I.

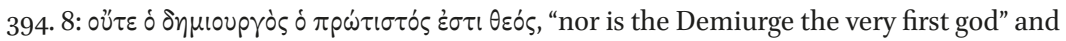

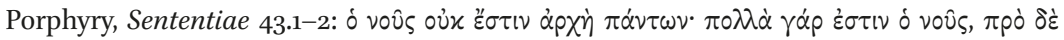

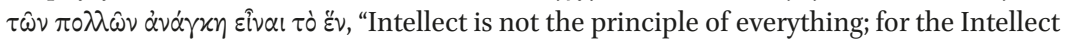
is many, while before the many there necessarily has to be the One." The supremacy of Intellect is most probably applicable only to the sensible world.

41 See, e.g., In Ti. I. 366. 9-20; 393. 11-13; 395. 11-13, 396. 3-8, where the divine Intellect ( $\theta$ cî́ vov̂s) is respectively said to engage in the activity of demiourgia and is equated with the Demiurge.

42 See Proclus, In Ti. I. 308.19-309.6; Opsomer 2006, 277-78. For further similarities between Iamblichus' and Proclus' understanding of the Demiurge, see Lecerf 2012. 
the tenet of the gradual diffusion of unity, ${ }^{43}$ and recognizes the distinction between intelligible and intellective principles. This makes Plotinus' original triadic scheme much more complex. Hence, Proclus, like Plotinus and Porphyry, places the Intelligible, taken in the broadest sense of the word, below the hypostasis of the One; unlike them, however, he differentiates the triad of Being, Life, and Intellect proper within the second hypostasis. ${ }^{44}$ These stand respectively for an intelligible (noêton, what is intellected), intelligible-intellective (noēton-noeron), and intellective principle (noeron, what intelligizes). Proclus locates the Demiurge within the third constituent of the triad, namely Intellect, and in this respect, he is in agreement with Plotinus. However, his love of ontological fastidiousness allows him to be more precise than his great predecessor; thus, Proclus' Demiurge represents "the limit of the intellective [entities]"45 — which means that he is the last member of the first intellective triad comprising the Intellect. ${ }^{46}$ Not without remarkable speculative dexterity, Proclus manages to ground the main thrusts of his argument in the text of the Timaeus, gathering additional support from the Orphic hymns and the Chaldean Oracles.

First, it is beyond dispute that the Demiurge is a nous (and subsequently not a soul of any kind, as Porphyry was - justly or unjustly — accused of claiming), because Plato calls him "nous" (Timaeus 39a7). The same appellation makes it clear that this he is not one of the intelligible-intellective entitiesbecause nous always intelligizes, while the statement "he gazed at the everlasting [Paradigm]" (29a3) distinguishes him from the intelligible gods, since the object of intellection is the Paradigm, i.e., the Intelligible Being. Hence, the Demiurge must be one of the intellective entities. Furthermore, he cannot stand at the forefront of the intellective triad because that god is fixed in his own customary èthos (42e5-6), i.e., remaining immersed in inner activity alone-while the Demiurge is outwardly creative. He also cannot be the second god of the triad, because that member is always the cause of life. Now,

43 The aims of this strategy are to insulate the first god, the One, from any immediate link with the multiplicity of the Intellect, while at the same time providing a detailed explanation of the lower hypostases' manner of procession.

For the subsidiary triad to on-zōe-nous, see Elem. Theol. § 101-103, and Dodds' Commentary $(1963,252-54)$.

45 In Ti. I. 311.2. See also I. 310.9.

46 There are two triads in the Intellect - "the parents" and "the immaculate," plus "the seventh divinity." The former's members are the pure intellect (Kronos), the intellective life (Rhea), and finally the demiurgic intellect (Zeus). In a longish theological section of his commentary (I.312.26-317.20.), Proclus explains how and why both Orpheus and Plato celebrate the Demiurge as Zeus. 
the Demiurge does generate soul, but only with the assistance of Hera, the mixing bowl (41d4), while by himself he creates and imparts only nous (3Ob4). Therefore, he is primarily the cause of intellection, and thus the third member of the first intellective triad. ${ }^{47}$

Finally, Plato also calls the Demiurge "the best of causes" (29a6), in order to tell him apart from the lesser gods invested with demiurgic causal power. ${ }^{48}$ All these points taken together proclaim that the Demiurge is "an intellective god transcending all other demiurges." $49 \mathrm{He}$ is the monad responsible for primary creation, the provider of universal providence, the first Zeus, upon whom the hypercosmic demiurgic triad depends. ${ }^{50}$ The latter represents the second Zeus, who is also the first god of the triad (the other two being his Homeric-Hesiodic brothers, Poseidon and Hades). ${ }^{51}$ And yet, this is not where Proclus' story of the Demiurge ends. Below the Timaean Demiurge and the first demiurgic triad there arises another monad and a second triad, ${ }^{52}$ but any discussion regarding these entities remains beyond the purview of this chapter.

In summary, this brief exploration of the three productive phases of Platonism leads to the following conclusions: (a) in the Old Academy, the figure of Plato's Demiurge is conspicuous by its absence; (b) although the Middle Platonists waver-identifying the Demiurge with the World Soul, with the first god, the Good, the secondary, creative Intellect — by the end of the period he is clearly profiled as an entity more fundamental than the soul; (c) if not with Plotinus, then at least with the post-Porphyrian Neoplatonists, after centuries of interpretative turmoil, the question of the Demiurge receives a definite answer, as far as one of its most crucial aspects is concerned-Plato's divine craftsman is universally understood to stand for a transcendent Intellect, both

47 See In Ti. I.311.2-311.25.

48 At In Ti. I.310.15-18, Proclus presents four types of demiurgic causation: (a) that of a demiurgic cause that produces universal beings universally (which is the demiurgic monad, i.e., the Demiurge of the Timaeus); (b) the one that produces partial beings universally (the first, hypercosmic demiurgic triad); (c) the demiurge of universal beings acting partially (the hypercosmic-encosmic gods); d) the cause of partial being acting partially (the encosmic, i.e., Timaeus' younger gods).

49 In Ti. I.311.13-14.

$5^{\circ}$ This is also what Orpheus holds, according to Proclus: see In Ti. I.313. $5^{-6 .}$

$5^{1}$ The difference between the Demiurge and the first demiurgic triad, as well as their respective creative tasks, powers, etc., are explained in detail by Proclus in Theologia Platonica VI.6-10.

These are items (c) and (b) of fn. 48 supra. 
separate from and superior to the World Soul, while at the same time subordinated to the Good.53

\subsection{Modern Critics and the Demiurge}

The present segment is intended to serve as a synopsis of some of the most prominent and most recent readings, relatively speaking, of the Demiurge, against which the conclusions of the chapter's last section will be set. These debates have their origins in the late nineteenth century, when, with the renewal of interest in Plato's Timaeus, the Demiurge once again became a subject of scholarly interest. The quest for discovering his identity was initiated afresh, as if it had never before been undertaken, a task now also supervenient on a plethora of philosophical ideas unknown to the ancients. Subsequently, most of the conclusions the critics have arrived at remain within the already traced lines, while nevertheless occasionally striking a rather distinctive note in comparison with those of the ancient Platonists.

Probably a prime example of the latter phenomenon is the conclusion reached by R. D. Archer-Hind, the author of the first of the three major English commentaries on the Timaeus (the other two being, of course, those of A. E. Taylor and F. M. Cornford). Indeed, the status that Archer-Hind assigns to the Demiurge is rather novel and not readily discernible from the text itself. $\mathrm{He}$ pays his dues by engaging with earlier interpretations and infers that Timaeus' account of creation must be taken as "pure poetry," beneath the veil of which "lies a depth of philosophical meaning," to be unearthed by the reader, as well as that the "Artificer of the universe" is not a personal, transcendent god, nor prior or external to the Forms. ${ }^{54}$ What does the Demiurge stand for, then? Well, he is rightfully identifiable with the Good (auto to agathon), ${ }^{55}$ provided one is able to deliver a correct interpretation of the latter. And this is where the author's own philosophical convictions come to the fore. Since Archer-Hind is a panpsychist (of Hegelian provenience), the Demiurge, for him, is the auto to agathon, but also the World Soul, or, more precisely, a specific phase of it, that of aloofness and purity, i.e., absolute separateness from matter. This aspect of the World Soul is, however, nothing other than the universal nous - pure reason or absolute thought - which is, in the world of Archer-Hind, also identical with

\footnotetext{
53 A more detailed discussion of Middle Platonic and Neoplatonic views on Plato's Demiurge is given in Opsomer 2005.

54 Archer-Hind 1888, 37-39.

55 Archer-Hind 1888, 39, 91 n. 12.
} 
the Good itself. Plato's Demiurge thus becomes the nous/auto to agathon, ${ }^{56}$ i.e., the universal spirit- though at the stage before it instigates the development of the One into the Many and their mutual unification into a conscious unity, and Platonic philosophy as a whole becomes a form of pantheism..$^{57}$

Also current among interpretations is the notion that the Demiurge is a mythical representation of the Paradigm, ${ }^{58}$ or, more precisely, of its dynamic and productive function. ${ }^{59}$ Matthias Baltes argues that Timaeus' god, being a principle, has to be there in the first ontological distinction made at $27 \mathrm{~d} 6-$ $28 \mathrm{ar} ;{ }^{60}$ but if so, then he must somehow be incorporated into the on of $5^{2 \mathrm{~d}} 3$. However, from $48 \mathrm{e}$ onward it has been clear that this on (i.e., of both $27 \mathrm{~d} 6$ and $5^{2 \mathrm{~d}} 3$ ) is the Paradigm; therefore, the Demiurge and the ideal model in its entirety (i.e., the intelligible world as a whole) are identical. This is confirmed by the statements that the noêton $z \bar{o}(i)$ on contains within itself all intelligible $z \bar{o}(i) a,\left(305_{5}-31 \mathrm{a} 4\right)$ and that the Demiurge is the most excellent of all eternal and intelligible beings (37a1). ${ }^{61}$ The result of this line of reasoning is a concept basically non-different from Plotinus' Demiurge, who stands identified with the philosopher's second hypostasis.

Taylor's view on the Demiurge, though informed by some Christian concepts and Whitehead's ontology, is much closer to the (pre-Plutarchian) traditional interpretations. His analysis is clear-cut, and its main features seem to be as follows: (a) Timaeus' creation story is to be taken allegorically, i.e., there has never been an actual state of chaos and disorder that needed to be organized; (b) the cause of the universal order is the Demiurge, who is the only God in Plato's system, separate from the Paradigm, omniscient and omnibenevolent; ${ }^{62}$ (c) on the strength of the evidence in the Sophist (249a4-8), ${ }^{63}$ Taylor urges that the ordering nous Socrates brings up in the Phaedo — as well as, for that matter, its much improved counterpart in the Timaeus - cannot either

56 Other recent critics who identify the Demiurge with auto to agathon-though in a different way and for different reasons - include Stewart, who held that the Good of the scientific Plato is the religious Plato's Demiurge (1905, 101-2), Zeller (1922, 710-18), and Wood (1968), who took the Demiurge to be a mythical personification of the Good.

57 Archer-Hind 1888, 39-40.

58 See Baltes 1996.

59 See Ferrari 2007, 156-63, esp. 161.

6o This is, of course, the distinction between "that which always is, without being involved

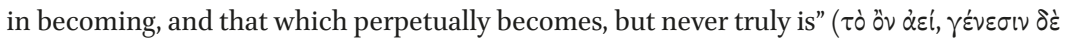

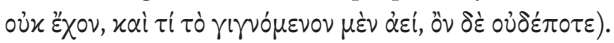

61 Baltes 1996, 82.

62 See Taylor 1928, 76, 82 .

63 This is corroborated in Phlb. 3oc9-10, Ti. 3ob. However, Taylor does not mention those two loci at this juncture. 
exist or exercise agency apart from soul; ${ }^{64} \mathrm{~d}$ ) this, in conjunction with Laws $896 \mathrm{~d}_{5}-8$, where it is stated that soul is the cause of everything, including the good and the bad, ${ }^{65}$ makes him conclude that Plato's God, the Demiurge, is a soul, and, moreover, aristē psychē, the best, absolutely good soul, identifiable with the Cosmic Soul of the Laws. ${ }^{66}$

R. G. Bury, who authored the Loeb translation of the Timaeus, initially seems to be in favor of the Demiurge as "the embodiment of 'the Good' regarded as efficient Cause", 67 perhaps on account of his Christian background. However, for reasons of inconsistency of the thesis and fidelity to the letter of Plato's dialogues, he is bound to separate the Demiurge from the Paradigm and the Forms in general, as well as to recognize him as nous, best identifiable with the cause of the Philebus. Finally, having in mind the same concerns as Taylor, i.e., the mythical character of the account and the alleged inseparability of intellect from soul, Bury comes to a different conclusion, namely that "the Demiurge is no separate Power or independent divinity, but merely a part or faculty of the World-Soul".68

Perhaps surprisingly, Cornford declines to distinctly pinpoint the Demiurge's identity and position, claiming that " $\mathrm{t}]$ his is precisely the question that Plato refused to answer." ${ }^{\prime 9}$ Nevertheless, he does make several important claims. First, the creation account related in the Timaeus is not to be taken literally. ${ }^{70}$ Second-and in response to Taylor's insistence that Timaeus' creator-god is Plato's supreme and only God-Cornford asserts that the Demiurge is not a religious figure, not an object of worship, nor an omnipotent creator. ${ }^{71}$ Third, the Demiurge, who obviously represents the cosmic Intellect, or nous, is distinct and separate from the Paradigm, while not separate from the world he is depicted as creating. ${ }^{22}$ Finally, cashing in on Plato's seemingly unambiguous statement that Intellect can be found only in soul, as well as on Timaeus' depiction of the universe as a god-a whole composed of body, soul, and nous - Cornford proposes that Plato might have envisioned the Demiurge as a

\footnotetext{
64 Taylor 1928,77 .

65 Taylor $1928,72,78$.

66 Taylor $1928,71,72,75,76,77,82$.

67 Bury 1929, 7 .

68 Bury 1929, 10.

69 Cornford (1937) 1997, 38 .

70 " $[\mathrm{B}]$ oth the Demiurge and chaos are symbols: neither is to be taken quite literally, yet both stand for real elements in the world as it exists" (Cornford [1937] 1997, 37). It turns out that they represent the innate sources of order and disorder, respectively.

71 See Cornford (1937) 1997, 35, 36, 38.

72 Cornford (1937) 1997, 38, 39.
} 
representation of divine Intellect, which is inseparable, and thus non-distinct, from the World Soul and the cosmos. ${ }^{73}$

Harold Cherniss is yet another advocate of the allegorical reading of the Timaeus and understands its account of creation to be but a "mythical form of exposition." ${ }^{74}$ Consequently, the Demiurge is not meant to be taken literally either. ${ }^{75}$ Still, he must have a place in Plato's system. One thing is rather obvious in this regard, i.e., that the Demiurge represents nous. ${ }^{76}$ However, Cherniss also affirms that nous cannot exist apart from soul, ${ }^{77}$ so the god of the Timaeus must be a divine soul endowed with nous, i.e., the World Soul. Now, here comes the twist: that nous - which is identical with the One of the Philebus, also denominated as "cause" - is not an entity in its own right, but the World Soul's faculty for contemplating the Forms and transferring their structure onto the creation. ${ }^{78}$ Thus, Plato's Demiurge "[i]s not 'god' but a logical abstraction, 'intelligent causation' in general."79

Another interpretation from the first half of the twentieth century must be mentioned, because, together with the previous three, they comprise a set from whose boundaries most of the later construals do not diverge. It is authored by Hackforth, who, like the other modern scholars mentioned so far, believes that both the creation story and the Demiurge are mythical images, for which, however, factual equivalents should be sought, and which are not to be explained away. Unsurprisingly, Hackforth identifies the Demiurge with nous, which is, however, this time separate from, and more fundamental than, the World Soul. ${ }^{80}$ The latter viewpoint makes him disagree with Taylor, Cornford, and Cherniss on another crucial issue; despite the allegedly decisive textual evidence, he holds that this nous can exist apart from soul, while the relevant passages are concerned merely with the universe and the entities within it. They all only have nous, but are not themselves a nous. ${ }^{81}$ Unlike those, the

73 Cornford (1937) 1997, 39. And, more emphatically: "It becomes more than ever difficult to resist the inference that the Demiurge is to be identified with the Reason in the World Soul" (Cornford [1937] 1997, 197). It is obvious that Cornford was led to a view very similar to that of Bury.

74 Cherniss 1944, 431.

75 See Cherniss 1944, 425 .

76 Cherniss 1944, 605.

77 Cherniss 1944, 425, 6o6-7.

78 For a rather complementary outlook, see Archer-Hind 1888, 93 n. 7.

79 Cherniss 1944, 607.

8o Hackforth 1936, 4 .

81 Hackforth 1936, 7 . 
Demiurge is an independent nous, the transcendent-immanent God, and the first principle of late Plato.

It has already been mentioned that most of the subsequent twentieth- and twenty-first-century interpretations are variants of the last four readings discussed above. Thus, Carone, not unlike Taylor, holds Plato's creator-god to be a mythical representation of the World Soul, ${ }^{82}$ but also, in affinity with Cornford, that the World Soul stands for "[ $t]$ he mind or principle of organization of the universe, which does not exist independently of it but rather necessitates a body, as [...] every intellect and every soul does in Plato's late work." ${ }^{33}$ Finally, almost rephrasing Cherniss, she emphasizes the Demiurge's abstractness and factual purpose of embodying "intelligent causation aiming at an end." 84

Yet, the advocates of the separate nous thesis seem to have become more prominent in recent decades. This group, although obviously sharing the most important common postulate, is not characterized by a firm unanimity of opinion. For example, one of its distinguished representatives, W. K. C. Guthrie, sees the Demiurge as the hypercosmic God of theistic Plato, clearly distinguishable from the World Soul and the encosmic demigods. He is a divine Intellect, separate from the Forms and the productive cause of the creation, identifiable with the great cause of Philebus $23 \mathrm{~d} .{ }^{85}$

In an effort allied to those of Hackforth and Guthrie, Mohr takes issue with the claim that nous cannot exist unless incorporated within a soul. He argues that the related textual evidence pertains to instances when nous is already in something, i.e., to an intellect such as ours, which needs to be both ensouled and embodied. This does not cover the case of the Demiurge, who is not contained anywhere, but is instead a transcendent God, pure Intellect, and artificer of souls and ensouled creatures. ${ }^{86}$ Mohr thus objects to the tendency to explain the Demiurge away, and takes him as a real figure, i.e., a "non-reducible

82 Other critics who understand the Demiurge as identical to the World Soul include Vlastos (1967), Tarán (1971), and Fronterotta (2012, 16-18).

83 Carone 2005, 28.

84 Carone 2005, 31. All the aforementioned points, as well as the final conclusion that the Demiurge is a symbol of the World Soul and its intellective functions, are elaborated in Carone 2005, 42-52.

85 See Guthrie 1978, 215, 253-62.

86 See Mohr 2005. His intervention is especially important because it addresses Cherniss' assertion that, although the relevant Timaeus and Philebus passages could be interpreted away as definite proofs that the nous is dependent on soul for its existence, the Sophist $248 \mathrm{e}-249 \mathrm{~d}$ is unambiguous in this regard. Mohr argues, in my opinion successfully, that the Sophist as well is reconcilable with the reading that recognizes the existence of an unensouled nous in Plato. 
component of the Platonic metaphysics." 87 The Demiurge's interventions are primarily aimed at an epistemological end, which is to improve the world's intelligibility and thus facilitate the formation of true opinions. ${ }^{88}$

The most comprehensive bid to establish a Platonic ontology of the Demiurge is Stephen Menn's, who dedicated his Plato on the God as Nous primarily to the exploration of this topic. Menn by and large joins the route already trodden by Hackforth, Guthrie, and Mohr, and argues extensively in favor of the Demiurge's separateness from the World Soul ${ }^{89}$ and his identity with the nous of the Philebus and Laws XII. ${ }^{90} \mathrm{He}$ seems to prefer a non-literal reading of the Timaean creation story, ${ }^{91}$ while his most important and distinctive thesis is that the demiurgic nous is not "Mind" but the virtue of rationality. ${ }^{92}$ Of course, Plato allows for virtues to exist in themselves, but they must be Forms. Menn naturally embraces this conclusion, and eventually asserts that the nous of the Timaeus and the other dialogues is a Form, though of a special kind: it is one capable of exerting not only formal, but also efficient, causal power, the constantly active cause of universal order. ${ }^{93}$

Similar to Menn's approach, to a certain degree, is that of Johansen, inasmuch as he interprets the Demiurge as the continually active, abstract principle that restores order whenever and wherever necessary, and also helps himself to some Aristotelian ideas while constructing his exposition. Plato's Demiurge now turns out to be a manifestation of craftsmanship, i.e., a personification of the productive and ordering techne, which is also the creation's productive cause..$^{94}$ This is the most novel feature of Johansen's take, while the rest of it is in conformity with Hackforth and others: the divine techne in question is essentially a nous acting from outside the universe, separate from both the World Soul and the Forms - the non-literal reading of the Timaeus is thus the safest. ${ }^{95}$ In essence, this interpretation is also affiliated to the conclusions of Luc Brisson's impressive elucidation of the Demiurge and his role in the Timaeus and beyond. For Brisson, Plato's father and maker is a nous distinct from the Forms, distinct from the nous of the World Soul and the World Soul itself, and a productive agent endowed with thought, will, emotion. He is a

\footnotetext{
$87 \quad$ Mohr 1985, 131.

88 See Mohr 1985.

89 Menn 1995, 13-24.

90 Menn 1995, 10, 18.

$91 \quad$ Menn 1995, 51.

92 Menn 1995, 15-16, passim.

93 Menn 1995, 44-47, 57-59.

94 Johansen 2004, 84.

95 See Johansen 2004, 69-91.
} 
god-however, not a personal one, but instead a representative of the universal order, a function whose actions are diversified according to the nature of the creations that are to be produced. ${ }^{96}$

Sarah Broadie shares many of the tenets accepted by the group that prefers the separate nous interpretation. ${ }^{97}$ Thus, the Demiurge is a creative and ordering nous separate from the cosmos and different from the World Soul. ${ }^{98}$ Besides the novel and complex arguments presented in support of these conclusions, her main contribution to the debate seems to be the (welcome) shift from an allegorical to a literal reading of Timaeus' creation story. The upshot of Broadie's investigations in this matter is that Plato was serious about the proto-historical beginning of the cosmos, even if his temporal account cannot be characterized as fully coherent. ${ }^{99}$

It is my hope that the selection given in the main body of this section suffices to illustrate what I take to be a general trend: modern and contemporary critics have explored a varied range of interpretative possibilities, while the second half of the twentieth century and the last two decades have witnessed an increased interest in the view that most naturally emerges from the textual evidence: the Demiurge is a nous. However, opinions significantly differ on whether it is transcendent or immanent, as well as on its more detailed specifications.

\subsection{What Plato Really Thought: A Modest Proposal}

The debate centered around the Demiurge's status has indeed been substantial, although there are not many alternatives one can opt for in that regardthe problem being, essentially, of an exegetical nature. This fact makes the bid to join the discussion that much more difficult, but certainly not redundant. One way to embark on such a task is to step all the way back to square one, with a view to revising the basics.

The noun demiourgos and its cognates, in their philosophically relevant sense, appear in the Republic, as well as in possibly all of Plato's late dialogues, excluding the Critias. These are the Sophist, the Statesman, the Philebus, and

\footnotetext{
96 See Brisson 1998, 32-36, 53, 70.

97 Yet another representative of this view is Karfik (2007), who holds the Demiurge to be a thinking and acting divine Intellect.

98 Broadie 2012, 7, 13, 17-24. She is not forthright about the separateness of the Demiurge from the Paradigm but affirms that they are at least different in function $(2012,27)$.

Broadie 2012, 22-24, 243-77.
} 
the Timaeus, ${ }^{100}$ while Mohr claims, based on a single analogy in Laws 9o2e4-5, that the divinity of Laws $\mathrm{x}$ is also a demiurge. ${ }^{101}$ The word is prosaic enough: it primarily means "skilled manual worker who produces goods for others."102 A critic glosses it as "a craftsman, an artisan, someone who makes (poiein) things by pursuing a techne.". ${ }^{103}$ Additionally, in some city-states, the term also served as a title of a magistrate. ${ }^{104}$ It is attested as such in Thucydides, which implies that Plato was most probably aware of that connotation. Both these senses are meaningfully applicable to the Demiurge, although one may wonder what prompted Plato to associate his creator-god with a person of such lowly social status as the Athenian demmiourgos. ${ }^{105}$ Perhaps the reason is the most obvious one. Namely, the Timaean maker of the cosmos is functionally nondifferent from any ordinary craftsman: as the latter produces an amphora by turning to a model and working on the already available clay, in much the same way the former gazes at the divine Paradigm and fashions this world using preexistent material. In other words, the crux of the matter might have been to emphasize the productive capacity of the Demiurge, his role as a causal agent.

The seed of this idea is probably sown in the Cratylus $389 a-390 a$, where the onomatourgos or the nomothe $s^{106}$ is called the rarest of craftsmen ${ }^{107}$ and compared to a carpenter who fashions a loom shuttle, inasmuch as both artisans generate their product by gazing at and reproducing its eidos. ${ }^{108}$ At Republic $529 \mathrm{~d}_{7}-53 \mathrm{Ob} 4$ this analogy acquires theological and cosmological import. The passage is imbedded within a broader discussion of the spiritual ineffectuality of the practice of mundane astronomy. ${ }^{109}$ Its main purport is to suggest

\footnotetext{
100 The ordering here is somewhat random, since it is of little importance for the issue.

101 See Mohr 1978, 573 and cf. Brisson 1998, 30. This is, however, a contestable suggestion.

102 Liddell et al. 1996, 386.

103 Sallis 1999, 5 o.

104 Brisson $(1998,50-54 ; 84-97)$ elaborates extensively on this meaning.

105 See Gregory 2008, xxxii. However, Brisson (1998, 84-101) offers a very erudite and detailed argument that is meant to justify Plato's choice of the term as the best possible description of his creative and ruling cosmological principle.

106 The name-maker or lawgiver, i.e., the inventor of words.

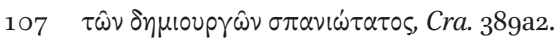

108 Cf. Resp. 596b-d. Also Gorg. 503d-504b, where the dēmiourgoi are said to be responsible for ordering and organizing their material.

109 Resp. 529a-53oc. This seems to stand in opposition to Timaeus $46 \mathrm{e} 7-47 \mathrm{c} 4$, where the capacity to observe celestial phenomena is said to be the greatest benefit effectuated by the organ of sight, and consequently the very reason for its bestowal upon mortals by god. Because, in this way men acquire first mathematics, then philosophy, and finally become eligible to harmonize the revolutions of their souls with those of the World Soul. However, it could very well be that the contradiction resolves itself once one recognizes the different contexts of the Timaeus and Republic passages; in the first one Plato's focus
} 
that just as even the most masterfully drawn diagrams cannot express the true mathematical ratios that govern geometric figures, so the visible heavens, as intricately construed as they may be, fall short of conveying the ideal number and relations of motion, as well as the realm of Being. Therefore, one should abandon observational, and embrace pure mathematical astronomy. What is of special interest for us here is the example of Daedalus, an adept craftsman, ${ }^{110}$ who draws complex diagrams which serve as blueprints for his mobile statues, and the parallel that is drawn between him and god, the craftsman of the heavens, ${ }^{111}$ who shaped the celestial vault as excellently as possible, given the material. ${ }^{112}$ Both the diagrams and the heavens can be used only as visible models that facilitate rational inquiry into the eternal realities and connections they represent. The relation is in this case inverted as far as the Timaean model-copy concept is concerned, i.e., the product now becomes, in a sense, a paradigm - but that is immaterial; the key point is the comparison of the world with a work of art or technical ingenuity, and of its creator with an artisan who manufactures it. There are no serious obstacles now left for applying the term demiourgos to both a human craftsman and the creator-god.

The second sense of the term, i.e., the one related to the office of a magistrate, also fits well with the cosmological function of the Demiurge. For he not only creates the world, but also governs it through his appointed representatives, and even personally introduces the "laws of destiny" to the individual souls (Timaeus $41 \mathrm{e}-42 \mathrm{e}$ ).

The most important Platonic text on the Demiurge is, of course, the Timaeus, where this enigmatic figure plays a central role in the psychogonic and cosmogonic events. It is introduced in a remarkable way, as if not only to borrow the appellation from the ordinary craftsman and apply it to the god, but also to make the resemblance between the former and the latter obvious. At 24a, while the anonymous priest is presenting the Egyptian (and, by analogy, the ancient Athenian) social division to Solon, the caste of craftsmen (dêmiourgoi) and its various subunits are brought up. Next, from 28a on, the reader learns that any craftsman (dèmiourgos) who aims at producing a beautiful object directs his gaze at the changeless paradigm. ${ }^{113}$ Finally, at $28 \mathrm{c}$, the world's creator is called

is on the starting point of the spiritual evolution, in the second he discusses the gateways of dialectic as the final stage of one's ascent to the Good.

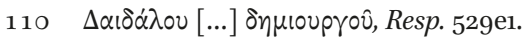

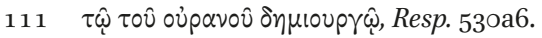

112 Which is another reversed echo of the Timaeus.

113 This is possibly a tacit allusion to the relevant Cratylus passage, as well as an intimation of the cosmic craftsman's activity. 
into the picture, and described as its maker (poiètese), father (patēr), and artificer (ho tektainomenos). However, when presented in his full glory, as the best of causes (aristos tön aition) and the benevolent (agathos) god by whom the cosmos has been crafted (dedèmiourgètai), he becomes known as the Demiurge $\left(29 a 2-29 b_{1}\right)$. This is the title that stuck and has remained in vogue to date, exactly because of the vividness and simplicity of the simile with the all too well-known common craftsman, the producer of things. Plato refers to the god as a Demiurge again at 41a7, as the maker and father of things indestructible; at $42 \mathrm{e} 8$, where he is the maker of the younger gods; at $68 \mathrm{e} 2$, where he, unlike Necessity, is the maker of what is the most beautiful and best; at 69c, where the divine elements of the world are said to be fashioned by him. As though to strengthen the productive force of the metaphor, i.e., to enunciate its essentially efficient ${ }^{114}$ character, other poiettai, both sentient and inanimate, are also addressed by Plato as dêmiourgoi, or their activity is typified as dèmiourgein. These are the younger gods (41c, $\left.46 \mathrm{e},{ }^{115} 69 \mathrm{c}, 75 \mathrm{~b}\right)$, the planet earth (4Oc), the element of fire (59a), and Necessity (76d).

Yet, as has been mentioned already, the Timaeus is far from the only relevant dialogue as far as the Demiurge is concerned. In the Sophist, during the final, successful bid to define the sophist through the method of division (Soph.264b268d), the Eleatic Stranger proposes a partition of the productive art ( $\dot{\eta} \tau \varepsilon \chi \chi \eta$

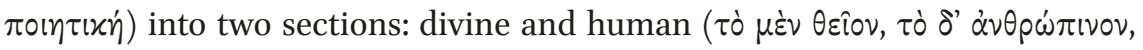
265b6). ${ }^{116}$ The practitioner of the divine productive art is, of course, god, who gives rise to all living being and lifeless substances by having recourse to reck-

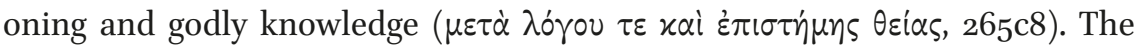
divinity of Sophist $265^{a-265 d}$ is a craftsman-god ( $\theta \varepsilon 00 \hat{~ \delta \eta \mu r o v p r o v ̂ v \tau o s, ~ 265 c 4) ~}$

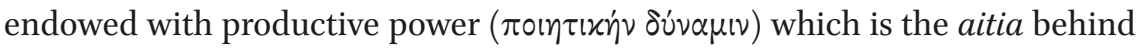
the coming to be of things that previously were not (265b8-10).

The Statesman is probably even more specific. In the dialogue's great myth (268d-274e), the Eleatic Stranger promises to weave together three traditional

114 The employment of this term, of course, does not imply that Plato worked with or recognized Aristotle's taxonomy, but only that, with the benefit of hindsight, we could discern in his ruminations on causality something alike to the Aristotelian efficient cause, or, more broadly, to the common concept of efficiency as productive action of a conscious agent. There have been precedents regarding the application of the phrase "efficient cause" to Plato's thought; see, e.g., Menn 1995, 46.

115 Here, both the younger gods and the Demiurge are implied, because they are all "craftsmen of things beautiful and good" (46e4).

116 The former is responsible for natural entities, which are thus made by divine art

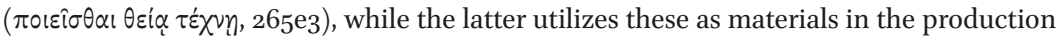
of various artefacts. 
tales - those of the quarrel between Atreus and Thyestes, of the earth-born people and of the Hesiodic golden age ${ }^{117}$ - by pointing out the single unifying condition due to which they all arise $(26 \mathrm{gb}-\mathrm{c})$. This turns out to be the periodic reversal of the universe's rotation: sometimes it is under god's direct care and rotates from west to east, while at other times god retires and the universe revolves in the opposite direction. ${ }^{118}$ The principal reason behind this alteration is the world's corporeal nature, which prevents it from remaining permanently self-same and unchanged. Be that as it may, a point of special importance here is that the divinity who oversees these events, the creator and the governor of the universe, is not only identified as a craftsman (demmiourgos 270a5), but also lauded as its "Demiurge and father" (tou dèmiourgou kai patros, 273b1-2). 119

Lastly, there is the discussion of four kinds (eidē) of beings (ta onta) at Philebus $23 \mathrm{c}-27 \mathrm{c}$. As it is well known, these are the unlimited (to apeiron), the limit (to peras), their mixture (to symmisgomenon), and the cause (aitia, $23 \mathrm{~d} 7$, $26 \mathrm{e}-27 \mathrm{c1}$ ) that blends the first two. The last kind, or principle, is said to be Intellect (nous, $28 \mathrm{c1-31a3}$ ) and a productive cause (26e6-8). ${ }^{120}$ As if to specify the type of productive activity that this nous performs, Plato also describes it as the craftsman who makes (to dèmiourgoun) all things that come to be. ${ }^{121}$

None of this information, of course, fully answers the questions regarding the Demiurge's nature, status, and importance, but it nevertheless contains unmistakable hints that point the reader in the right direction. I believe that the following probable account can be of use in discerning this direction and

117 A brief elucidation of these three motifs and references to other Plato's dialogues where they are mentioned or alluded to is given in Vidal-Naquet 1978, 136-137.

118 The number and the nature of the cosmic rotations has become a debated issue. For references to several key participants in the debate and some novel solutions, see chapter 1 in this volume.

119 It is of little interest for our purpose to enquire whether this god is Zeus, Kronos, or yet another deity (some thoughts on this issue can be found in, e.g., Gartner and Yau 2017, 454-55); what matters is the fact that he is being characterized - in language reminiscent of the Timaeus - as a demiurgic entity.

120 The equivalence between nous and aitia is confirmed at Phil. 30a1o-3oez.

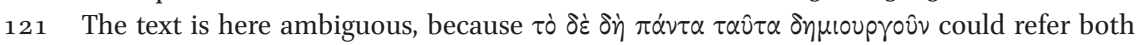
to $\pi \dot{\alpha} \nu \tau \alpha \tau \dot{\alpha} \tau \rho^{\prime} \alpha$... $\gamma \varepsilon \dot{\varepsilon} \eta$, i.e., to the three kinds of unlimited, limit, and mixture, as well as to $\tau \dot{\alpha} \mu \dot{\varepsilon} \nu \gamma \curlyvee \gamma \nu{ }^{\mu} \mu \varepsilon v \alpha$ (27a11-12). However, considering that the first two kinds are themselves independent principles, that the mixture is repeatedly referred to as something that comes into being, and that at $23 \mathrm{~d} 7$ and $27 \mathrm{bg}$ the fourth kind is explicitly said to be its cause, it is safe to conclude that Plato does not want to say that the cause of the Philebus produces all three kinds, but only the mixture, i.e., the becoming. 
ultimately in lifting the veil of mystery that surrounds Plato's Demiurge, who in all apposite late dialogues appears as an intelligent productive agent.

The first upshot of the relevant passages in the Timaeus and the related dialogues is that the creator-god and his exploits are not to be taken lightly or dismissed as mere allegory; on the contrary, they play an indispensable role in Plato's later metaphysics and cosmology. This can be made obvious by applying a simple abstraction experiment.

Let us imagine for a moment that we know nothing of Plato's ontology and causal theory as they have been learned from the Phaedo and the Republic. What are we left with in the late dialogues? In a nutshell, the Forms are still there, but their prominence is rather limited; the "classical" doctrine of the Forms is subjected to serious revision (the Sophist), ${ }^{122}$ and their causal role is minimized and confined to the subordinate, paradigmatic one (the Timaeus). What we do have instead is an increased insistence on the causal and overall importance of soul and nous. One of the key reasons for such divergence is the difficulty hinted at in Phaedo 99c-d, where Socrates proclaims himself (temporarily) unable to investigate and grasp-if I may paraphrase- "the godly force of the cause that works for the best," and therefore settles for his second voyage, which is the (imperfect) formal explanation of the perceptible phenomena. ${ }^{123}$ This implies the whole cluster of problems concerning Plato's twoworld theory, but primarily the issue of the link—or lack thereof—between the Forms and the particulars, including the standard answer given to it, i.e., the notion of participation. ${ }^{24}$ This is obviously too large and complex an issue to be discussed here; however, it should be noted that much of the Timaean cosmogony may have been conceived as an attempt to clarify "how it is that nous sets in order and causes everything,"125 i.e., to provide a tenable teleologi$\mathrm{cal} /$ efficient causal explanation of the relation between the worlds of Intellect and sense. ${ }^{126}$ That is also the reason why, in Plato's late period, in general the causality of Forms remains a dormant concern, while precedence is given to

\footnotetext{
122 See e.g., Kahn 2007.

123 See $P h d$. 99c1-3. For a radically different interpretation of the 99c passage, according to which Socrates in the Phaedo does not abandon the quest for teleological cause, see Vázquez 2020.

124 metalèpsis, methexis. It is evidently unsatisfactory, and never actually spelled out, except in purposefully obscured language; see e.g., Phd. 10oc-d, Symp. 210e-211b. It was subjected to honest criticism in Prm. 130e-131e.

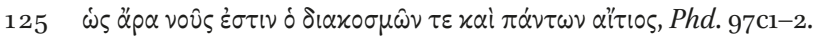

126 See Lennox 1985, who argues that the divine craftsman makes the cosmos good by implementing ideal mathematical structures. See also chapters 3 and 4 in this volume.
} 
the causal output of active and intelligent agents, most importantly to nous or god.

The epitome of such divine causal agency in late Plato is the Demiurge of the Timaeus and the other dialogues of the group. He organizes the initial chaos by somehow projecting upon it the transcendent realities $\left(53 b_{4}-5\right)$ and installs the Cosmic Soul as an everlasting mediator between the eternal and the temporal realm. Considering the extraordinary role he has been granted, it is reasonable to assume that his metaphysical status will not be any less vital, either. As mentioned at the beginning of the section, the options in this respect - those for which the text allows - are but few: when not completely rejected as an ontic and explanatory entity, the Demiurge was identified in the ancient world with the World Soul, the Good, the Paradigm, the Intellect, and with god, and in recent times with the Good or another Form or collection of Forms, the World Soul, as well with an immanent or transcendent nous, sometimes construed as an impersonal productive and ordering principle, sometimes as God.

It seems that none of these opinions has been conclusively dismissed in twenty-first-century scholarship, although the separate nous thesis (in its few variants) has perhaps gained a firmer foothold. Now, before briefly reviewing them, it is important to spell out the interpretational perspective that underlies my approach. I endorse a strong literal reading of the creation story, ${ }^{127}$ which is, among other things, almost necessitated by Myles Burnyeat's widely accepted interpretation of the eikōs mythos locution as a (probable but) reasonable account. ${ }^{128}$ The crucial implication of such an approach is that the

127 That is, of its central cosmogonical and cosmological features; it is not that I am committed to the obviously fantastic images, like the mixing bowl where the soul-stuff is kneaded (41d). It is impossible here to defend this position, which also represents the most natural approach. For a synopsis of the debate among adherents of the literal and metaphorical reading, see Zeyl 2000, xx-xv. For a more comprehensive list of the spokespersons for both views, see Carone 2005, 204 n. 19. For an alternative take, which aims at reconciling the opposed readings (the so-called perpetual, or on-going creation view), see Johansen 2004, 87-91 (esp. 90-91), and Carone 2005, 31-35. A conveniently brief selection of arguments in favor of the literal reading is given in Sedley 2007, 99-105.

128 Burnyeat 2005. In this article, he does not promote the literal reading explicitly. However, if Timaeus' account is "well reasoned like any of the PreSocratic cosmogonies" (145), if its purpose is to provide a series of practical reasons why the cosmos is as it is (158), if "the more appropriate or reasonable the account of some phenomenon, the greater the possibility of its being true" (163), etc., then it is perhaps wise to surmise that Plato did not conceive of his eikos mythos as a didactic fairy tale, but as a fair attempt at laying out a proper cosmogony, at least as sound as those of his predecessors, and perhaps more so. On the contrary, Fronterotta $(2012,16)$ holds that the eikos logos phrase implies a metaphorical reading. 
Platonic cosmos has a beginning ${ }^{129}$ and that it was created by a rational agent who, through the medium of the sempiternal World Soul, superimposed shape, proportion, and regularity on the factually existing disorderly material plenum. ${ }^{130}$ This efficient causal factor is, evidently, the Demiurge.

It is almost equally evident that Plato did not intend the Timaean creator to be a representation of his most celebrated class of intelligibles, i.e., the Forms. First, he is neither a part of, nor is he to be identified with, the complex of Forms that is to $z \bar{o}(i)$ on auto. Timaeus' own words exclude this possibility - the Demiurge contemplates, ${ }^{131}$ or gazes on, the Paradigm (Timaeus 28a-29a), which implies that he is somehow external to it. ${ }^{132}$ Someone may object that Plato here presents a case of self-contemplation; however, this proposal is not warranted by textual evidence and also leaves unexplained the peculiar ontological and causal status of the Timaean nous. I believe that the tendency to identify the latter with the Paradigm is partly prompted by the attempt to preserve exegetical economy, i.e., to elucidate the cosmogony of the Timaeus without admitting an additional entity into Plato's metaphysics. However, its proponents seem to end up doing exactly that, by assuming that the totality of Forms is a structure more perfect than its parts, the former being endowed with powers of self-contemplation and efficient causation of which the parts in themselves are devoid. ${ }^{133}$ This may be an attractive suggestion, but it reflects Neoplatonic rather than Platonic metaphysics, where there are no indications of such a concept. The same cannot be said of the possible existence of a separate nous. Thus, it appears that the latter thesis is in fact more economical than the former.

Furthermore, (a) nowhere in the Platonic corpus are the Forms called theos or nous (as the Demiurge is), nor is any god proclaimed to be an

129 However, not in time. Time is related to the motions of the World Soul and is coeval with the universe, while the state of being of the Demiurge and the Forms is eternity. The temporal beginning question thus becomes inadmissible. This view can potentially help in resolving the related worries of the Demiurge's pre-creational inactivity and withdrawal of benevolence. See chapter 4 in this volume.

130 In this case, the reverse strategy is applicable as well; that is to say, if the following understanding of the Demiurge has some claim to plausibility, it could be used as a further argument in support of the literal reading.

131 The importance of the states of cognition and knowledge for the notion of the Demiurge is emphasized in Karfik 2007.

132 The nous-ideai divide is once again emphasized at 39e7-8. The question whether the Forms are themselves external to the divine Intellect, or rather constitute its content - an outlook that gained prominence at least with Philo Judaeus-is of little importance for this discussion.

133 See Ferrari 2007, 161-62. 
eidos; ${ }^{134}$ and, (b) even if efficient causal power cannot be with absolute certainty denied of the Forms, ${ }^{135}$ they emblematically cause by being participated in, while the epitomes of efficient causality in Plato could only be soul and nous. In the Timaeus in particular, the Forms are both clearly paradigmatic causes and distinguished from the efficient one, which is theos dêmiourgos. ${ }^{136}$

Second, the Demiurge cannot be equated with the highest of Forms, to autoagathon. As already noted by Numenius (fr. 20) and Proclus (In Platonis Timaeum commentarii I. 306.7-9), Plato claims that he is agathos (Timaeus 29a3, 29e1), not tagathon. And again, nowhere is the Good said to be a god and nous, or to exercise any creative or ruling power over the world of sense-as the Demiurge is and does. This assertion is susceptible to a very natural objection: we have the case of the Good of Republic 508a-509b, which is qualified as the cause of the other Forms' being and intelligibility, and which is likened to the sun of this world and its cognitive and generative role. However, this should not be used to collapse the Demiurge into the Good. The latter there presides over the intelligible world, not the physical one, while the sun analogy is nothing more than that - an illustrative analogy meant to enhance understanding of the relations within the realm of Forms. The reader is not supposed to conceive of our sun as some kind of image or representation of the Good that creates and informs the Becoming.

Third, it is hardly possible that Plato's creator-god stands for a unique Form of nous, as Menn argues extensively. While nous can refer to the virtue of rationality ${ }^{137}$ — which is a crucial step in Menn's argument, for every Platonist would further accept the existence of the hypostasized virtue as a separate reality_one may doubt that this is the sense in which it is applied to the Timaean cosmogony. Not only is it plain that Plato does use nous both in the sense of the faculty for noesis, ${ }^{138}$ and, implicitly, to designate the substance that is its seat, ${ }^{139}$ but also the nous of the Timaeus - and of late Plato in general-is easily relatable to these two meanings. It clearly contemplates

134 The common objection that Ti. 37a refers to the Demiurge as a Form, naming him "the best of the intelligible beings," has been answered already by Cherniss (1944, 605): "the reference here to the demiurge [...] means nothing more than does 'intelligible' as used of soul in Laws 898D-E." That is, Plato recognizes other intelligible entities besides Forms, and he is free to apply the term noètos to any one of them. See also Plutarch's Quaest. Plat. 1002B: "For, god is among the intelligible beings."

135 As Aristotle does, but Menn $(1995,55)$ and possibly Fronterotta $(2007,53)$ decline to do.

136 Cf. De an. proc. ${ }_{1023}$ C.

137 See Menn 1995, 14-18.

138 See e.g., Resp. 511 .

139 This is the soul's rational, or divine, part. 
the Forms and, perhaps less clearly, represents a separate principle and entity. Again, even if we concede that Menn's peculiar Form of nous is efficiently efficacious, Plato's texts go further than simply postulating an impersonal source of change, ${ }^{140}$ and instead introduce a rational agent who makes deliberative, informed, good choices, and who is also a cognitive subject, even one endowed with emotional states. In the Timaeus, the Demiurge thinks (hègeomai, 30a5) and reckons (logizomai, 3ob1), but also desires (boulomai, 3oa2), feels delight and gladness (agamai and euphrainō, 37c); in the Sophist (265c) he ratiocinates, having recourse to divine knowledge. Furthermore, at Statesman 26ge, there is a statement to the effect that the leader of all things - whom I take to be the demiurgic god of the dialogue ${ }^{141}$ - constantly revolves around himself (auto de heauto strephein aei, 269e5), which is most probably a metaphor for a steadfast, uninterrupted, intellective motion. ${ }^{142}$ It is hardly unlikely that such properties could be admitted of a Platonic Form, regardless of how novel a notion of it one may try to introduce. Therefore, explaining the Demiurge as the Form of the Intellect might not be the most fortunate choice.

Next, the Demiurge is also not to be associated with the World Soul, as either its equivalent or its part. This is so for reasons similar to some of those aforementioned: first, the Demiurge of the Timaeus is obviously external to the World Soul. Moreover, and unlike the case of the Forms, he is also its originator. This has been taken to be a controversial topic; however, the idea of the soul's strong dependence on a higher principle is present in quite a few late dialogues. In the Timaeus the Demiurge is said to be the World Soul's maker, who constructed her as prior to and older than the body in birth and eminence. ${ }^{143}$ At Statesman $269 \mathrm{c}^{-} \mathrm{d} 3$ the Stranger basically reiterates the main points of Timaeus' cosmogonic account: the revolving world is a living being endowed with intelligence and fitted together in the beginning by the god. Philebus 3od1-4 indicates that the cause, which is nous that acts demiurgically,

140 This type of change would include the development of the animal seed, or billiard balls hitting one another. The same objection applies to Johansen's (2004) interpretation as well because the capacity for intellection and even sentiment can hardly be attributed to an abstract force of craftsmanship.

141 Because there is little doubt that the Statesman appellations "god" (269c5), "he who puts the world together" (269d1), "begetter" (269d9), "the self-revolving one" (269e5), "leader" (269e6), "divine cause" (270a3), "craftsman" (270a5), etc., are all meant to have the same referent, namely the world's creator and governor, who shows a strong affinity with the divine craftsman of the Timaeus.

142 For, Plato at Laws $897 \mathrm{~d}-898 \mathrm{~b}$ depicts the nature of rational motion, i.e., perfect rationality, by comparing it with a sphere continuously revolving round a fixed point.

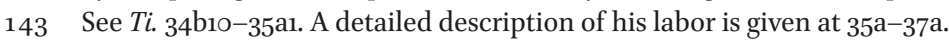


is responsible for nothing less than controlling and manipulating the World Soul. Lastly, the Laws leaves little doubt that soul and genesis go hand in hand. Thus, the Athenian at Laws 892a2-5 laments over human ignorance of the soul's origin (genesis), which is among the first existents, prior to bodies. At 892c3-4 psyche is gegenemēne $\bar{e}$, brought into existence, before fire or air; at $896 \mathrm{cl}-2$, it comes into being (gegonenai) earlier than the body; at 892 b1, 892c6, $896 \mathrm{~b} 2-3$, and 966d9-e 2 it is said to be older than the body or the oldest (presbytate $\bar{e}$ ) of all things, while from $967 \mathrm{~d} 6-7$ on, we learn that it is both the oldest

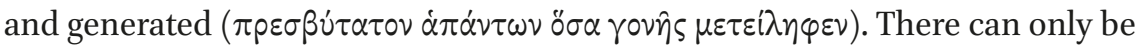
one originator and director of the Platonic soul —he whom Plato himself identifies as such.

What we are left with is the most natural interpretation: the Demiurge is a nous of some kind. This should go without saying, since in the Timaeus and the Philebus the terms nous and demiourgos clearly refer to the same entity. ${ }^{144}$ Obviously enough, Plato's claim in the Sophist, Philebus, and Timaeus that nous cannot exist apart from soul ${ }^{145}$ obliged many distinguished scholars to presume that the Demiurge, who is a nous, must be somehow associated with the World Soul; however, this position has been thoroughly examined and successfully refuted by Hackforth (1936), Menn (1995), Mohr (2005), and Broadie (2012), and is no longer binding. ${ }^{146}$

Thus, it seems that the historical-exegetical evolution of the understanding of the Demiurge both in ancient times and in our age led to a similar result. In the twilight of antiquity, the late Neoplatonists were unanimous in identifying Plato's Demiurge with Intellect, their second hypostasis, superior and prior to the World Soul; in recent years, although no definite consensus has been reached, several eminent scholars have put forward strong arguments in favor of the separate nous interpretation that remain unrefuted. Considering, too, what has already been said in this section, that seems to be the right approach regarding what Plato intended to convey through his creator-god figure. In conclusion, I shall try to add some nuance to this rather vague inference.

Plato envisioned the Demiurge as a separate Intellect, distinct from both the Forms and the World Soul. His activity, as described in the Timaeus, is twofold: contemplative, when he eternally intellects the Forms, ${ }^{147}$ and productive,

\footnotetext{
144 This is also valid for aition and theos.

145 See fn. 63 supra.

146 The gist of their argument is as follows: the relevant passages' import is that intellect must be attached to a soul only when already in something, like a body — be it individual or universal, i.e., the world. They do not, therefore, exclude the possibility of a separate, unembodied, and — most importantly—unensouled nous.

147 This is, after all, the primary role of any nous, as per Ti. $5^{1 \mathrm{~d}-} 5^{2 \mathrm{a}}$.
} 
when he uses that intellection to shape the primordial chaos-internally prompted by his inherent goodness ${ }^{148}$ —into the sempiternal god that is this cosmos. The Demiurge is thus an intelligent cause, a transcendent active principle behind the generation of this single and best of all possible worlds. To borrow Gail Fine's turn of phrase, Plato's creator-god is an E-aitia with a Tconstituent. ${ }^{149}$ That is, as the original source of change and orderly motion, he embodies the principle of efficient causation, ${ }^{150}$ while as an entity permeated and defined by the desire to do good - and by acting upon it - he fulfils the teleological function as well. In other words, the Demiurge is a rational productive agent who acts for a purpose, which is the implementation of beauty and goodness on the stuff of creation, as far as possible.

This leaves little doubt that the demiourgos of the Timaeus is non-different from the nous, poiètês, and aitia of the Philebus (26e-30e), who also bestows soul and nous to Zeus, i.e., the cosmos (Philebus 3od). ${ }^{151}$ Accordingly, the Demiurge emerges as a key figure in late Plato, although his identity is not clearly spelled out. Nevertheless, it seems reasonable to state that Plato amended his views on causality and metaphysics in general, as well as that his theism grew strong in the last twelve or so years of his life. ${ }^{152}$ By introducing the mysterious maker and father, he possibly came as close to the concept of a monotheistic God as the Greek mind could get. ${ }^{153}$ Besides being a transcendent Intellect, he is also a personal creator and orderer, led to his actions by the desire to do good. Evidently, the acceptance of this thesis implies admitting a novel, hitherto unknown entity into Plato's ontology—perhaps one whose nature and status even Plato himself was pondering, and which he chose not to explicate. ${ }^{154} \mathrm{On}$

148 See Ti. 29e-3oa.

149 Where $\mathrm{E}$ and $\mathrm{T}$ stand for efficient and teleological, i.e., final aitia respectively. See Fine 2003 .

150 To reiterate, as if to unambiguously associate his best of causes (aristos tōn aitiōn, 29a6) with active agency, Plato uses direct and simple language and refers to him with the names: father and maker (poiètēs kai pater, 28c3), artificer (ho tektainomenos, 28c6), craftsman (dèmiourgos, 29a3).

151 Brisson goes even a step further and claims that the four genera of the Philebus overlap with the inherent ontological structure of the Timaeus. Nous is, clearly, the Demiurge, mikton stands for the phenomenal world together with its soul, apeiron for the chöra, and peras for the Forms (Brisson 1998, 102-3).

$15^{2}$ See Taylor (1949, 371), who apportions the entire group of late dialogues to this period.

153 Nonetheless, its provenience is more similar to the theistic Vedanta concept (which includes the Supreme God Viṣnu and a plethora of generated demigods), than to its Judeo-Christian counterpart. At any rate, Plato's god would be only omnibenevolent and omniscient, but not omnipotent.

154 A bid for elaborating on Plato's notion of the divine Intellect as the highest god is made in Hackforth 1936. 
the other hand, the attempt to demythologize the Demiurge, i.e., to reduce him to the World Soul or any known Form or collection of Forms, would mean doing an injustice to the letter and purport of the Timaeus, Philebus, Laws, and, by implication, all the late dialogues. For they do proclaim the existence of an autonomous nous, which reigns over soul and matter, is a cognitive subject and a self-conscious productive agent, and represents the missing link in the Phaedo's ontology and causal theory. This is the prime cause of the creation, the great god, the often misunderstood but still unneglectable principle of late Plato, made famous under the name of the Demiurge.

\section{Acknowledgements}

My sincere gratitude goes to Silvia De Bianchi, Federico M. Petrucci and Daniel Vázquez, whose support and comments were instrumental in improving earlier versions of this chapter. I am also indebted to the two anonymous referees, whose objections helped me resolve further inaccuracies. This research is part of proteus "Paradoxes and Metaphors of Time in Early Universe(s)", a project that has received funding from the European Research Council (E RC) under the Horizon 2020 research and innovation programme (Grant agreement No. 758145).

\section{References}

Archer-Hind, Richard D. 1888. The Timaeus of Plato:Edited with Introduction and Notes. London: Macmillan.

Baltes, Matthias. 1972. Timaios Locros: Über die Natur des Kosmos und der Seele. Leiden: Brill.

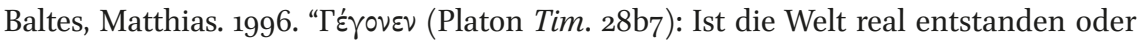
nicht?" In Polyhistor: Studies in the History and Historiography of Ancient Philosophy, edited by Kiempe A. Algra, Pieter W. van der Horst and David T. Runia, ${ }_{76-96 .}$ Leiden: Brill.

Bonazzi, Mario. 2012. "Antiochus and Platonism." In The Philosophy of Antiochus, edited by David Sedley, 307-33. Cambridge: Cambridge University Press.

Boys-Stones, George R. 2012. "Antiochus' Metaphysics." In The Philosophy of Antiochus, edited by David Sedley, 220-36. Cambridge: Cambridge University Press.

Boys-Stones, George R. 2018. Platonist Philosophy 80 BC to AD 250: An Introduction and Collection of Sources in Translation. Cambridge: Cambridge University Press. 
Brisson, Luc. 1998. Le même et l'autre dans la structure ontologique du Timée de Platon: Un commentaire systématique du Timée de Platon. Third edition. Sankt Augustin: Academia Verlag.

Broadie, Sarah. 2012. Nature and Divinity in Plato's Timaeus. Cambridge: Cambridge University Press.

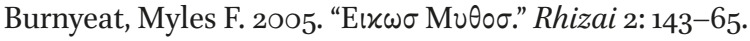

Bury, Robert G. 1929. Plato:Timaeus, Critias, Cleitophon, Menexenus, Epistles. Cambridge, Mas.: Harvard University Press.

Carone, Gabriela R. 2005. Plato's Cosmology and Its Ethical Dimensions. Cambridge: Cambridge University Press.

Cherniss, Harold F. 1944. Aristotle's Criticism of Plato and the Academy. Baltimore: The John Hopkins University Press.

Cherniss, Harold F. 1976. Plutarch: Moralia vol. XIII, Part 1. Cambridge: Harvard University Press.

Chiaradonna, Riccardo. 2015. "Plotinus' Account of Demiurgic Causation and Its Philosophical Background." In Causation and Creation in Late Antiquity, edited by Anna Marmodoro and Brian D. Prince, 31-50. Cambridge: Cambridge University Press.

Cornford, Francis M. (1937) 1997. Plato's Cosmology: The Timaeus of Plato. Indianapolis: Hackett.

Dillon, John M. 1993. Alcinous: The Handbook of Platonism. Oxford: Clarendon Press.

Dillon, John M. 1996. The Middle Platonists: 8 o B.C. to A.D. 220. Ithaca: Cornell University Press.

Dillon, John M. 2002. "Plutarch and God: Theodicy and Cosmology in the Thought of Plutarch". In Traditions of Theology: Studies in Hellenistic Theology, its Background and Aftermath, edited by Dorotea Frede and André Laks, 223-237. Leiden: Brill.

Dillon, John M. 20oza. The Heirs of Plato: A Study of the Old Academy (347-274 BC). Oxford: Clarendon Press.

Dillon, John M. 2003b. "The Timaeus in the Old Academy." In Plato's Timaeus as Cultural Icon, edited by Gretchen J. Reydams-Schils, 8o-94. Notre Dame: University of Notre Dame Press.

Dodds, Eric R. 1963. Proclus: The Elements of Theology. Second edition. Oxford: Oxford University Press.

Ferrari, Franco. 2005. "Der Gott Plutarchs und der Gott Platons." In Gott und die Götter bei Plutarch: Götterbilder-Gottesbilder-Weltbilder, edited by Rainer Hirsch-Luipold, 13-25. Berlin: De Gruyter.

Ferrari, Franco. 2007. "Separazione asimmetrica e causalità eidetica nel Timeo." In La sapienza di Timeo. Riflessioni a margine del Timeo di Platone, edited by Linda M. Napolitano Valditara, 147-72. Milan: Vita e Pensiero. 
Fine, Gail. 2003. "Forms and Causes: Plato and Aristotle." In Plato on Knowledge and Forms: Selected Essays, edited by Gail Fine, 350-96. Oxford: Clarendon Press.

Fronterotta, Francesco. 2007. "The Development of Plato's Theory of Ideas and the 'Socratic Question.'” Oxford Studies in Ancient Philosophy 32: 37-62.

Fronterotta, Francesco. 2012. "El demiurgo y los principios del cosmos generado en el Timaeo de Platón." Cuadernos de filosofia 59: 5-22.

Gartner, Corinne, and Claudia Yau. 2017. "The Myth of Cronus in Plato's Statesman: Cosmic Rotation and Earthly Correspondence." Apeiron 53, no. 4: 437-62. Gregory, Andrew. 2008. "Introduction." In Plato: Timaeus and Critias, translated by Robin Waterfield, ix-lvii. Oxford: Oxford University Press.

Guthrie, William K. C. 1978. A History of Greek Philosophy, Volume V: The Later Plato and the Academy. Cambridge: Cambridge University Press.

Hackforth, Reginald. 1936. "Plato's Theism." The Classical Quarterly 3o, no. 1: 4-9.

Hankinson, Robert J. 2001. Cause and Explanation in Ancient Greek Thought. Oxford: Clarendon Press.

Johansen, Thomas K. 2004. Plato's Natural Philosophy: A Study of the Timaeus-Critias. Cambridge: Cambridge University Press.

Kahn, Charles H. 2007. "Why is the Sophist a Sequel to the Theaetetus?" Phronesis 52, no. 1: 33-57.

Karamanolis, George. 2006. Plato and Aristotle in Agreement? Platonist on Aristotle from Antiochus to Porphyry. Oxford: Clarendon Press.

Karamanolis, George. 2014. "Plutarch." In The Stanford Encyclopedia of Philosophy (Winter 2014 edition), edited by Edward N. Zalta. Accessed November 12, 2020. https://plato.stanford.edu/archives/win2o16/entries/plutarch/.

Karamanolis, George. 2013 "Numenius." In The Stanford Encyclopedia of Philosophy (Winter 2016 edition), edited by Edward N. Zalta. Accessed November 12, 2020. https://plato.stanford.edu/archives/win2o16/entries/numenius/.

Karfik, Filip. 2007. "Que fait et qui est le démiurge dans le Timée?" Études Platoniciennes 4: $129-5$.

Lecerf, Adrien. 2012. "Iamblichus and Julian's 'Third Demiurge': A Proposition." In Iamblichus and the Foundations of Late Platonism, edited by Eugene Afonasin, John Dillon, and John F. Finamore, 177-201. Leiden: Brill.

Lennox, James G. 1985. “Plato's Unnatural Teleology.” In Platonic Investigations, edited by Dominic O'Meara, 195-218. Washington, DC: Catholic University of America Press.

Liddell, Henry G., Robert Scott and Henry S. Jones. 1996. A Greek-English Lexicon. Ninth edition. Oxford: Oxford University Press.

Menn, Stephen P. 1995. Plato on God as Nous. Carbondale: Southern Illinois University Press.

Mohr, Richard D. 1978. "Plato's Final Thoughts on Evil:Laws X 899-905." Mind 87: 572-75. 
Mohr, Richard D. 1985. "Plato's Theology Reconsidered: What the Demiurge Does?" History of Philosophy Quarterly 2, no. 2: 131-44.

Mohr, RichardD. 2005. "The Relation of Reasonto Soulinthe Platonic Cosmology:Sophist 248e-249d." In God and Forms in Plato, 189-95. Las Vegas: Parmenides Publishing.

Noble, Christopher I., and Nathan M. Powers. 2015. "Creation and Divine Providence in Plotinus." In Causation and Creation in Late Antiquity, edited by Anna Marmodoro and Brian D. Prince, 51-70. Cambridge: Cambridge University Press.

O'Brien, Carl S. 2015. The Demiurge in Ancient Thought: Secondary Gods and Divine Mediators. Cambridge: Cambridge University Press.

Opsomer, Jan. 2005. "Demiurges in Early Imperial Platonism." In Gott und die Götter bei Plutarch: Götterbilder-Gottesbilder-Weltbilder, edited by Rainer Hirsch-Luipold, 51-99. Berlin: De Gruyter.

Opsomer, Jan. 2006. "To Find the Maker and Father: Proclus' Exegesis of Plato Tim. 28c3-5." Études platoniciennes 2: 261-83.

Petrucci, Federico M. 2018. Taurus of Beirut: The Other Side of Middle Platonism. London: Routledge.

Ryle, Gilbert. 1965. "The 'Timaeus Locrus.” Phronesis 10, no. 2: 174-9o.

Sallis, John. 1999. Chorology: On Beginning in Plato's Timaeus. Bloomington: Indiana University Press.

Sedley, David. 2002. "The Origins of Stoic God." In Traditions of Theology: Studies in Hellenistic Theology, its Background and Aftermath, edited by Dorotea Frede and André Laks, 41-83. Leiden: Brill.

Sedley, David. 2007. Creationism and its Critics in Antiquity. Berkley: University of California Press.

Sorabji, Richard. 1983. Time, Creation and the Continuum: Theories in the Antiquity and the Early Middle Ages. London: Duckworth.

Stewart, John A. 1905. The Myths of Plato, London: MacMillan.

Tarán, Leonardo. 1971. “The Creation Myth in Plato's Timaeus." In Essays in Ancient Greek Philosophy, edited by John P. Anton, George L. Kustas, and Anthony Preus, 372-407. Albany: State University of New York Press.

Tarrant, Harold, ed. and trans. 20o6. Proclus: Commentary on Plato's Timaeus Vol I, Book 1: Proclus on the Socratic State and Atlantis . Cambridge: Cambridge University Press.

Taylor, Alfred E. 1928. A Commentary on Plato's Timaeus. Oxford: Clarendon Press.

Taylor, Alfred E. 1949. Plato: The Man and His Work. Sixth edition. London: Methuen.

Thesleff, Holger. 1961. An Introduction to the Pythagorean Writings of the Hellenistic Period. Abo: Abo Akademi.

Vázquez, Daniel. 2020. “Teleology, Causation and the Atlas Motif in Plato's Phaedo." $\Sigma X O \Lambda E$ 14, no.1: 82-103.

Vidal-Naquet, Pierre. 1978. "Plato's Myth of the Statesman, the Ambiguities of the Golden Age and of History." The Journal of Hellenic Studies 98:132-141. 
Vlastos, Gregory. 1967. "Creation in the Timaeus: Is It a Fiction?" In Studies in Plato's Metaphysics, edited by Reginald E. Allen, 401-19 . London: Routledge and Keegan Paul.

Vorwerk, Matthias. 2010. "Maker or Father? The Demiurge from Plutarch to Plotinus." In One Book, The Whole Universe: Plato's Timaeus Today, edited by Richard D. Mohr and Barbara M. Sattler,79-100 . Las Vegas: Parmenides Publishing.

Wood, Richard J. 1968. "The Demiurge and His Model." The Classical Journal 63, no. 6: $255^{-58}$.

Zeller, Eduard G. 1922. Die Philosophie der Griechen in ihrer geschichtlichen Entwicklung, Vol II, $i$. Fünfte Auflage. Leipzig: O. R. Reisland.

Zeyl, Donald J. 20oo. Plato: Timaeus. Indianapolis: Hackett. 